\title{
Hygienic-Sanitary Profile of Handled Meat Sold in Bulk in Supermarket Chains in Teresina-PI
}

\author{
Olavo Dionísio da Silva Dias, ${ }^{1}$ Amanda de Oliveira Sousa Cardoso, ${ }^{1}$ \\ Letícia Batista dos Santos, ${ }^{1}$ Tiago Medeiros da Silva, ${ }^{1}$ Anderson de Melo Moreira, ${ }^{1}$ \\ Antonio Rosa de Sousa Neto, ${ }^{1}$ Lissandra Chaves de Sousa Santos, ${ }^{1}$ \\ Maria Eliete Batista Moura, ${ }^{1}$ Daniela Reis Joaquim de Freitas ${ }^{2}$
}

\begin{abstract}
The aim was to characterize the hygienic-sanitary profile of minced meat, fractionated chicken, ham and sausage, handled and sold in bulk in supermarket chains in Teresina-PI. Samples of sausage, ham, chilled chicken and minced meat were collected in five supermarket chains in Teresina-PI, identified as SM1, SM2, SM3, SM4, and SM5. Forty samples were analyzed by the methods of Faust, Willis and Faust adapted with alcohol-ether solution, in triplicates. Fungus spores, hyphae fragments, eggs (of hookworm and Ascaris lumbricoides) and cysts (Entamoeba coli) of parasites were found, as well as many insect body parts, as well as whole insects, such as fleas, mites and ants, in three of the five supermarkets evaluated in an amount higher than allowed by legislation. In two of the five supermarkets chosen for the research, no structures were found that could harm human health. It is necessary to implement good hygiene practices and care with meat storage in the supermarkets analyzed and to improve inspections by regulatory bodies. In addition, it is important to promote health education for supermarket workers, in order to avoid food contamination.
\end{abstract}

Keywords: Meat products. Bulk sale. Food microbiology. Health education.

\section{PERFIL HIGIÊNICO-SANITÁRIO DE CARNES MANIPULADAS E COMERCIALIZADAS A GRANEL EM REDES DE SUPERMERCADOS EM TERESINA-PI}

\section{RESUMO}

O objetivo deste estudo foi caracterizar o perfil higiênico-sanitário de carne moída, frango fracionado, presunto e salsicha manipulados e comercializados a granel em redes de supermercados em Teresina-PI. Amostras de salsicha, presunto, frango resfriado e carne moída vendidos a granel foram coletas em cinco grandes redes de supermercados de Teresina-PI, identificados como SM1, SM2, SM3, SM4 e SM5. Quarenta amostras foram analisadas pelos métodos de Faust, Willis e Faust adaptado com solução álcool-éter, em triplicatas. Em três dos cinco supermercados avaliados foram encontrados esporos de fungos, fragmentos de hifas, ovos (de verme ancilostomídeo e Ascaris lumbricoides) e cistos (Entamoeba coli) de parasitos, bem como muitas partes corporais de insetos, além de insetos inteiros, sendo estes pulgas, ácaros e formigas, em uma quantidade superior à permitida pela legislação. Em dois dos cinco supermercados escolhidos para a pesquisa não foram encontradas estruturas que pudessem prejudicar a saúde humana. É necessário implementar boas práticas de higiene e cuidado com o armazenamento de carne nos supermercados analisados e melhorar as inspeções dos órgãos reguladores. Além disso, é importante promover a educação em saúde para os trabalhadores do supermercado, afim de evitar a contaminação dos alimentos. Palavras-chave: Produtos cárneos. Venda a granel. Microbiologia de alimentos. Educação em saúde.

\footnotetext{
Universidade Federal do Piauí - Ufpi. Teresina/PI, Brasil.

Autora correspondente. Universidade Federal do Piauí - Ufpi. Centro de Ciências da Saúde, Campus Universitário Ministro Petrônio Portella - Ininga, Teresina/PI, Brasil. CEP 64049-550. http://lattes.cnpq.br/2308356617035380.https://orcid.org/0000-0002-5632-0332. danielarjfreitas@ufpi.edu.br
} 


\section{INTRODUCTION}

In recent years there have been noticeable changes in the behavior of consumers in several countries, especially concerning the increase in consumption of processed foods - also known as ultra-processed food - mainly by children and adolescents (NOLL et al., 2019). This fact is largely correlated with the growth of the food industry, due to the promotion of measures that influence purchasing, taking as examples the marketing and development of packaging/ products that generate convenience to the consumer (VICENTINI, 2015).

Amongst the industrialized foods most consumed by the population are those of animal origin, such as beef and chicken meat due to its practicality and its wide forms of consumption, whether in fast-foods, such as pastries, sandwiches, pizzas or even, in the complement of several dishes (TRAVASSOS; COELHO, 2017; SANTOS et al., 2017). Processed meat, such as sausages and hams also occupy a prominent position in the food industry, being consumed about five or more times a week (FLESCH; RAPHAELLI; WINCK, 2019).

Because of this widespread consumption, it is necessary to consider the specific hygienic-sanitary conditions of each country when slaughtering, transporting, preparing and packaging these foods of animal origin, in order to guarantee the quality and fundamental safety for consumption, avoiding Foodborne Diseases (FBD), which are infections caused by the ingestion of food and/or water contaminated by pathogens such as bacteria, viruses, and other parasites or by their toxins, that can affect humans causing morbidity and mortality (ÁVILA, 2016; BRASIL, 2019a).

Therefore, due to the constant increase in FBD and its possibility of causing outbreaks (NUNES et al., 2016), this study aims to search for indications of contamination by eggs or cysts of parasites in sausages, hams, fractionated chicken and minced meat sold in bulk in five supermarket chains located in the city of Teresina - PI. Thus, it will be possible to collaborate in the identification of health problems and to collaborate in the development of health education programs aimed at improving the hygienic-sanitary conditions of food products offered to the population in small and supermarkets.

\section{METHOD}

\section{Samples}

Samples of ham, sausage, minced meat, and chilled chicken sold in bulk, fractionated in styrofoam packaging were collected in five supermarkets in Te- resina, Piauí. The supermarkets were named as SM1, SM2, SM3, SM4, and SM5. Two of the five supermarkets that sold the products, had a single branch in the capital, while the rest had two or more branches. Eight samples from each supermarket were analyzed (two of each type of meat product, acquired at random and in duplicate), weighing between 100 and $400 \mathrm{~g}$ each, for a total of 40 samples.

\section{Sample collection procedure}

The collection of fractionated meat samples was carried out between March and May 2018. The samples acquired were immediately packed in plastic bags, sealed, and identified with the date of collection, weight, and time. The transportation of the samples to the laboratories took place, at most, after 4 hours of the collection, and it was carried out at a temperature between 25 and $28^{\circ} \mathrm{C}$, protected against humidity, light, and heat, through packaging in Styrofoam boxes.

\section{Macro and microscopic analysis}

All sample analyzes in question were performed in the laboratory of the Center for Studies in Microbiology and Parasitology (NUEMP), located at the Health Sciences Center (CCS) of the Federal University of Piauí (UFPI). The research for foreign macro and microscopic matters followed the recommendations of the Food and Drug Administration and was carried out based on the methodology used by Mennucci et al. (2010).

Each of the samples was placed on a surface lined with PVC film and analyzed macroscopically, through direct observation with the naked eye, to identify the presence of foreign matter. Then the samples were distributed on a plastic tray and cut, to verify the presence of foreign matter adhered in the internal parts of the product. If any foreign matter was found, the sample would be separated and placed in a Petri dish for later identification under a stereomicroscope.

After performing the macroscopic analysis, with or without the encounter of foreign matter visible to the naked eye, each sample was washed with $30 \mathrm{~mL}$ of distilled water, and subsequently analyzed through the adapted Faust centrifuge-flotation method (NEVES, 2016) using an ether-alcohol solution, and the Willis method (NEVES, 2016) adapted to verify parasitic structures such as protozoan cysts and helminth eggs. 
For the adapted Faust Centrifuge-Flotation Technique (NEVES, 2016), the $30 \mathrm{~mL}$ of distilled water used to wash the samples was placed in centrifugation tubes and centrifuged at 2,500 rpm. Then, the supernatant was discarded and the pellet resuspended in water; after a new centrifugation step, the supernatant was discarded and the pellet resuspended in a zinc sulfate solution $33 \%$, centrifuged again for one minute at 2,500 rpm, then the material was collected with a platinum loop, stained with Lugol on a microscope slide and examined in increments of 100x, 400x or 1000x. The material was analyzed immediately so that zinc sulfate would not deform the parasitic forms.

This procedure was also performed by replacing the zinc sulfate solution with an alcohol-ether solution (v: v) and examining the result also in an increase of 100,400 , and, if necessary, 1000X.

The Spontaneous Fluctuation Technique or Willis method (NEVES, 2016) was also used with adaptations. The samples were washed with a saturated $\mathrm{NaCl}$ solution and a microscope slide was placed in contact with the surface of the obtained solution, for $5 \mathrm{~min}$. After this period, the slide was quickly removed, returning the part in contact with the solution upwards and staining with Lugol, examining the result also in an increase of 100, 400, and, if necessary, 1000X.

The analyzes of all the techniques used were carried out in triplicate. Figure 1 shows the development flowchart and the set of methods used in summary form.

Figure 1 - Flowchart of sample collection and analysis

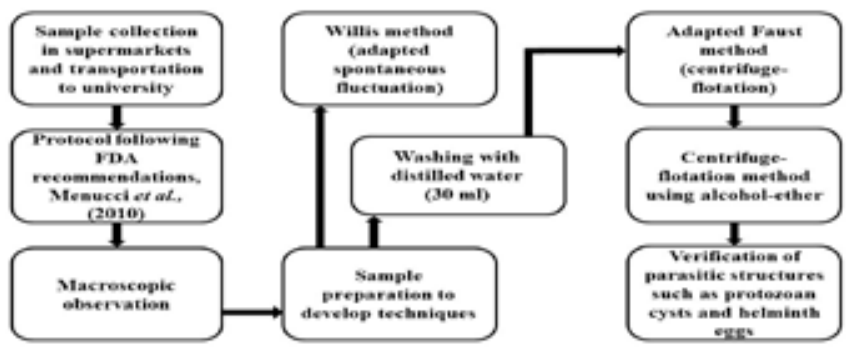

Source: Prepared by the authors (2020).

\section{RESULTS AND DISCUSSION}

A total of 40 samples were collected. There was no finding in the macroscopic analysis. Amongst the five supermarkets under analysis, 2 of them did not show any microscopic shape or structure that could cause an imbalance in human health. However, in the remaining 3, varied structures were found, as shown in Table 1.
Table 1 - Microscopic structures found in commercialized food at five supermarket chains in Teresina-PI

\begin{tabular}{|c|c|c|c|c|c|}
\hline $\begin{array}{c}\text { TYPE OF } \\
\text { FOOD }\end{array}$ & SM1 & SM2 & SM 3 & SM 4 & SM 5 \\
\hline SAUSAGE & $\begin{array}{c}\text { - Flea } \\
\text { - Hair } \\
\text { - Mite } \\
- \\
\text { Unidentified } \\
\text { insect egg }\end{array}$ & - & - & - & - \\
\hline HAM & $\begin{array}{l}\text { - Arthropod } \\
\text { fragments ( } 2 \\
\text { to } 3 \text { per field) }\end{array}$ & - & $\begin{array}{l}\text { - Arthropod } \\
\text { fragments ( } 2 \\
\text { to } 3 \text { per field) }\end{array}$ & - & - \\
\hline $\begin{array}{l}\text { MINCED } \\
\text { MEAT }\end{array}$ & $\begin{array}{c}\text { - Hypha and } \\
\text { fungus spores } \\
\text { - Entamoeba } \\
\text { coli cyst } \\
\text { - Ascaris } \\
\text { lumbricoides } \\
\text { egg (1) }\end{array}$ & - & $\begin{array}{c}\text { - Spores and } \\
\text { hyphae of } \\
\text { fungi } \\
\text { - Arthropod } \\
\text { fragments } \\
\text { - Ant }\end{array}$ & - & $\begin{array}{c}- \\
\text { Arthropod } \\
\text { fragment }\end{array}$ \\
\hline $\begin{array}{l}\text { CHILLED } \\
\text { CHICKEN }\end{array}$ & $\begin{array}{c}\text { - Insect wing } \\
\text { - Hypha and } \\
\text { fungus spores } \\
\text { - Hair } \\
\text { - Mite }\end{array}$ & - & $\begin{array}{c}- \\
\text { Ancylostoma } \\
\text { spp. larvae } \\
\text { egg } \\
\text { - Fungus } \\
\text { spores } \\
-3 \\
\text { Entamoeba } \\
\text { coli cysts }\end{array}$ & - & $\begin{array}{c}- \\
\text { Arthropod } \\
\text { fragment }\end{array}$ \\
\hline
\end{tabular}

SM: Supermarket.

Source: Prepared by the authors (2020)

According to Cunha, Stedefeldt, and Rosso (2012), the main FBDs caused by intestinal parasites are infections by protozoa (Giardia lamblia and Entamoeba histolytica) and nematodes (Trichuris trichiura, Strongyloides stercoralis, Enterobius vermicularis, Ascaris lumbricoides, Ancylostoma duodenale and $\mathrm{Ne}$ cator americanus). Thus, the findings in the present study are worrisome, since parasitic structures with pathogenic potential have been identified - both in minced meat and in chilled chicken, identified as: $E n$ tamoeba coli cyst, larvae of Ancylostoma spp. and Ascaris lumbricoides egg.

Alves et al. (2018) describe the presence of Sarcocystis spp., A highly pathogenic Coccidia protozoan in different meat products. This was not verified in our study since Sarcocystis is included in the animal musculature and there was no analysis of the musculature of the meat.

In the evaluated products, several fungi (hyphae and spores), insect eggs, several fragments of arthropods - including whole arthropods such as fleas, mites, and ants - and hair were also found. A study carried out with sausages acquired in the commerce of Joinville, a city in the state of Santa Catarina, identi- 
fied fungi, specifically Aspergillus sp. This information can be compared with data obtained in our study, not in sausages, but in minced meat and chicken (DANA; ROSA, 2018).

The presence of ants indicates the existence of damage in food packaging, given that they are classic carriers of microorganisms, as well as the presence of fleas - a frequent parasite of animals such as rodents, dogs, and cats. Besides, the presence of animal hair in more than one sample of meat (sausage and chilled chicken) suggests that the places of storage and/or transportation are visited by animals, which ends up putting the health of the consumer at risk. The presence and proliferation of these pests increase the chances of pathogens' transmission, which can cause the destruction and/or elimination of nutrients. However, even though the possibility of transmitting diseases to humans by arthropods and/or their traces in food has been proven, updated data on their identification in meat products are still scarce in the literature (SILVA; FULCO; BARBOSA, 2017). Figure 2 shows the findings of this work in the meat samples collected.

The parasitic structures described above can cause mild to severe diseases (BRASIL, 2019b), with great potential to cause mortality mainly in children living in places where basic sanitation, housing, and hygiene conditions are precarious (VON HUTH; KOFOED; HOLMSKOV, 2019). It is known that many people eat some types of rare or even raw meat, such as sausage and ham. This can be an extremely dangerous health factor, since ingesting these meats both children and adults are at high risk of contamination. The main clinical manifestations caused by the parasites identified in this study are explained in Table 2.

Figure 2 - Structures found in meat samples (sausage, ham, minced meat and chicken) fractionated and sold in bulk in supermarkets in Teresina, PI

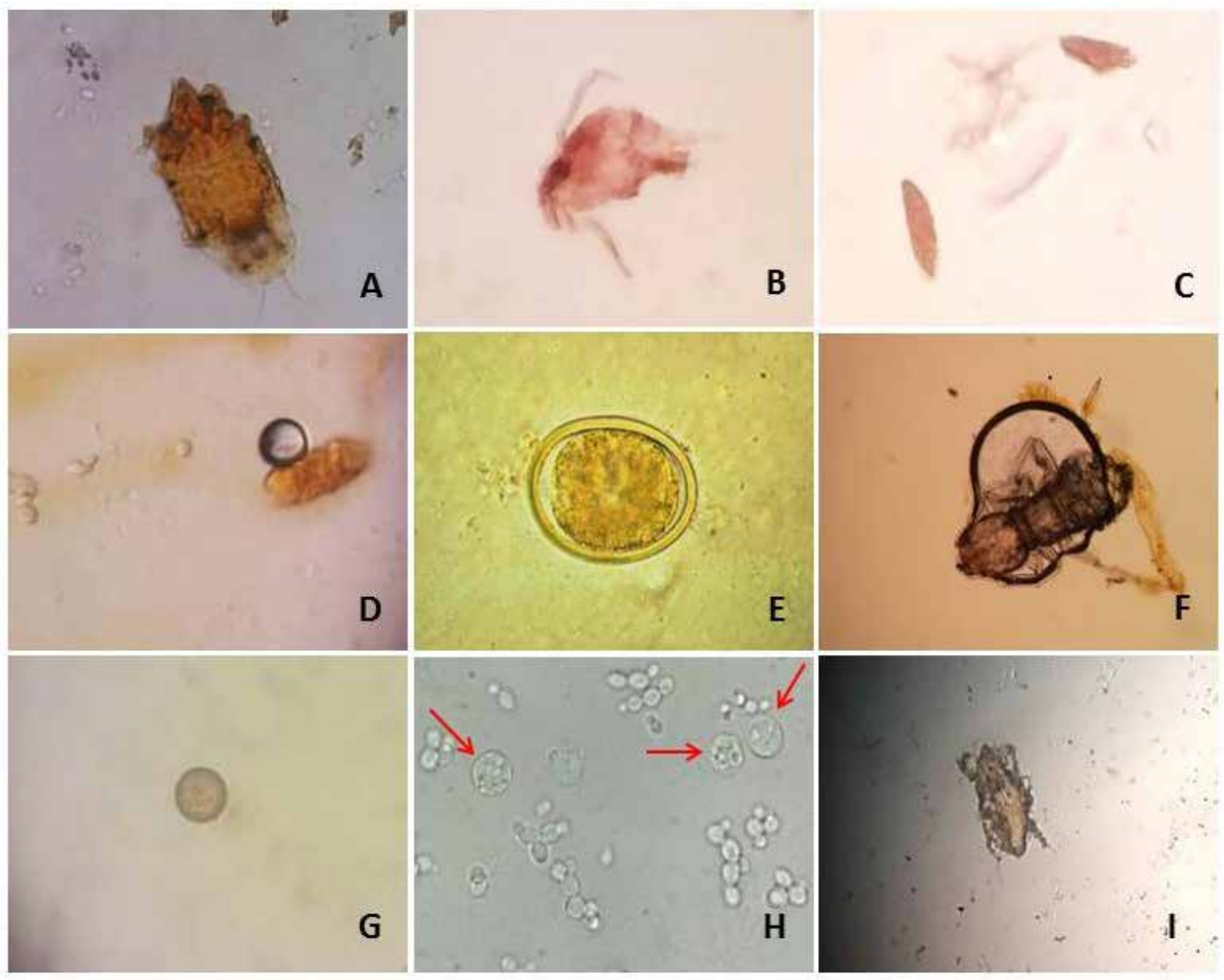

A, mite found in a sausage sample, in $40 \mathrm{X}$ magnification; $\mathbf{B}$, flea found in a sausage sample, at $100 \mathrm{X}$ magnification; C, insect eggs, found in sausage, at $100 \mathrm{X}$ magnification; D, hookworm egg, found in chilled chicken, at 100X magnification; And, Ascaris lumbricoides egg, found in minced meat, in 400X magnification; $\mathbf{F}$, ant found in minced meat, at 40X magnification; G, Entamoeba coli cyst found in minced meat, at 400X magnification; $\mathbf{H}, E$. coli cysts (indicated by arrows) found in chilled chicken, in 400X magnification; I, mite found in chilled chicken, in 40X magnification. 
Table 2 - Main clinical symptoms caused by parasites found in meat samples (sausage, ham, minced meat and chilled chicken) fractionated and sold in supermarkets in Teresina, PI

\begin{tabular}{ccl}
\hline Group & Agent & \multicolumn{1}{c}{ Main Clinical Manifestations } \\
\hline Protozoa & $\begin{array}{c}\text { Entamoeba } \\
\text { coli }\end{array}$ & $\begin{array}{l}\text { Diarrhea, mild to moderate } \\
\text { gastrointestinal disorders in general; } \\
\text { fatigue. }\end{array}$ \\
\hline & $\begin{array}{l}\text { Damage to the respiratory system } \\
\text { (dyspnoea, sputum, cough, } \\
\text { bronchitis, lung injuries), the digestive }\end{array}$ \\
Nematoda & $\begin{array}{c}\text { Ascaris } \\
\text { lumbricoides } \\
\text { and } \\
\text { hookworms }\end{array}$ & $\begin{array}{l}\text { abdominal pain, mechanical trauma } \\
\text { to the intestinal wall and intestinal } \\
\text { occlusions) and ectopic infections } \\
\text { (mainly in the liver, pancreas, duct, } \\
\text { and gallbladder). }\end{array}$ \\
\hline
\end{tabular}

Source: Prepared by the authors (2020).

According to the brochure "Good handling practices in food banks", among the main factors that promote the occurrence of FBD are the failures that occur during the production process, namely: inadequate handling, improper temperature, poor conservation, cross-contamination, hygiene deficient personnel, inadequate cleaning of equipment and utensils, as well as the contact of infected handlers with ready-to-eat food (BRASIL, 2006). However, what is currently noted is that hygienic-sanitary conditions are not yet followed by most establishments, evidencing findings such as this study (SANTOS et al., 2018).

In the case of minced meat, the grinding is an additional factor capable of favoring the contamination and the proliferation of microorganisms, since in this process the pathogens present on the surface can pass into the interior and consequently increase the development area; hence the fact that a large number of hyphae and fungal spores have been found in this meat type. In the case of chilled chicken, the main factors may be the roughness and pore on the skin, in addition to the high amount of fatty acids that promote the adhesion of pathogens (SILVA; JUNQUEIRA; SILVEIRA, 2017).

Besides, the presence of the structures identified in the current study highlights the lack of good hygienic-sanitary practices on the part of these employees. They end up maintaining direct contact with food at various times, whether in transport, fractionation of products in trays for sale in bulk, or storage, including the stage of making products available in refrigerated display cases in the supermarket. Silva et al. (2018) endorse this thought, by stating that the para- sitic handler has a strong ability to contaminate food, demonstrating that these professionals also have responsibility for food safety.

According to the Integrated Manual for Surveillance, Prevention and Control of Foodborne Diseases (BRASIL, 2010) the handler can also favor contamination by wearing ornaments (rings, earrings, watches, and others) since these objects can carry eggs and parasite cysts, and become the main route of dissemination. In this sense, it is necessary to guide and supervise these professionals so that they can respect hygiene practices in the workplace. Measures such as frequently cleaning hands with gel alcohol, using and sanitizing work machinery and Personal Protective Equipment (PPE) correctly avoid direct contamination (MEDEIROS et al., 2017; MOERMAN, 2017).

Brazilian legislation (Law No. 9,782 present in Ordinance No. 354 of ANVISA) (BRASIL, 2014) allows only the presence of arthropods or their parts in low quantities. In addition, the presence of pest insects in commercialized food is prohibited, such as cockroaches, ants, flies, or other arthropods that have the habit of maintaining contact with feces, corpses, and garbage. Barbers or other blood-sucking insects are also prohibited, whether at any stage of their development, alive or dead, whole or in parts. As a result of the findings in this study, it is necessary, in addition to the hygiene measures already described, to check the storage places and the transport trolleys for food products, keeping them clean and disinfected and not allowing the access of animals such as rodents, dogs, cats. There must also be the implementation of integrated pest management.

Due to the complexity of these infections for the clientele as well as for supermarket workers, lectures and courses are needed for workers in these commercial establishments, with a focus on health education. It is necessary to clarify the correct way of handling food, the means of conservation and storage, the importance of personal hygiene and food hygiene, and the etiology of foodborne diseases. Studies show that health education works are effective and can result in a major improvement in the hygienic-sanitary conditions of establishments, contributing beneficially to the health of the population and promoting social development (ROCHA et al. 2018; WU; LI, 2017).

It is the first time that a study which demonstrates parasitic structures on the outside of fractionated and commercialized meat in bulk is carried out, as the vast majority of studies focus on showing parasitic structures inside the meat, whether inspected or not. One of the limitations of this study was the techniques 
used, which had to be adapted for the study, as there are no techniques in Parasitology that could be fully repeated. Although the results have been satisfactory, the standardization of new techniques for the evaluation of macrostructures in food can be of great value for the control of food quality.

\section{CONCLUSION}

This study detected a series of contaminating structures in foods that are widely consumed by the population, which puts their lives at risk. Meat products like sausage and ham, which are eaten by many without cooking to become even faster to eat, are especially dangerous. There is a need for greater supervision by the competent bodies regarding food hygiene and storage, and the use of protective equipment inside supermarkets. Educating handlers, through lectures, job training courses, and personal care, in addition to providing a greater number of work uniforms to them to change their clothes more often, may be the key to avoiding damage to the health of the general population.

\section{REFERENCES}

ALVES, Marta Elena Machado et al. Caracterização molecular de Sarcocystis spp. em amostras de carne. Pesquisa Veterinária Brasileira, v. 38, n. 3, p. 425-429, 2018.

ÁVILA, Mariana de Oliveira et al. A importância do controle das condições microbiológicas e higiênico sanitárias na prevenção de doenças transmitidas por alimentos - uma revisão de literatura. Revista Expressão Científica (REC), v. 1, n. 1, p. 1-12, 2016.

BRASIL. Ministério da Saúde. Agência Nacional de Vigilância Sanitária. Resolução da Diretoria Colegiada $n^{\circ} 14$ de 28 de março de 2014. Dispõe sobre matérias estranhas macroscópicas e microscópicas em alimentos e bebidas, seus limites de tolerância e dá outras providências. Diário Oficial da União [Internet]. 2014 mar. Disponível em: http://bvsms.saude.gov.br/bvs/saudelegis/anvisa/2014/ rdc0014_28_03_2014.pdf. Acesso em 21 fev. 2020.

BRASIL. Ministério da Saúde. Doenças transmitidas por alimentos: causas, sintomas, tratamento e prevenção. 2019a. Disponível em: http://www.saude.gov.br/saude-de-a-z/ doencas-transmitidas-por-alimentos. Acesso em: 21 fev. 2020.

BRASIL. Ministério da Saúde. Guia de vigilância em saúde. 3. ed. Brasília: Ministério da Saúde, 2019b.

BRASIL. Ministério da Saúde. Secretaria de Vigilância em Saúde. Departamento de Vigilância Epidemiológica. Manual integrado de vigilância, prevenção e controle de doenças transmitidas por alimentos. Brasília: Editora do Ministério da Saúde, 2010.
BRASIL. Ministério de Agricultura, Pecuária e Abastecimento. Boas práticas de manipulação em bancos de alimentos. Rio de Janeiro: Embrapa Agroindústria de Alimentos, 2006.

CUNHA, Diogo Thimoteo; STEDEFELDT, Elke; ROSSO, Veridiana Vera. Boas práticas e qualidade microbiológica nos serviços de alimentação escolar: uma revisão sistemática. Revista Brasileira de Pesquisa em Saúde, v. 14, n. 4, p. 108121, 2012.

DANA, Eveline Cristina; ROSA, Tania Regina de Oiveira. Avaliação físico-químicas e microbiológica de salsichas adquiridas no comércio da cidade de Joinville/SC. Nutrição Brasil, v. 17, n. 2, p. 80-87, 2018.

FLESCH, Betina Daniele; RAPHAELLI, Chirle; WINCK, Samantha. Consumo de frutas, legumes e verduras em um censo escolar de zona rural. Revista da Associação Brasileira de Nutrição, v. 10, n. 1, p. 81-86, 2019.

HUTH, Sebastian Von; KOFOED, Poul-Erik; HOLMSKOV, Uffe. Prevalence and potential risk factors for gastrointestinal parasitic infections in children in urban Bissau, Guinea-Bissau. Transactions of The Royal Society of Tropical Medicine and Hygiene, v. 113, n. 9, p. 545-554, 2019.

MEDEIROS, Maria das Graças Gomes de Azevedo et al. Percepção sobre a higiene dos manipuladores de alimentos e perfil microbiológico em restaurante universitário. Ciência \& Saúde Coletiva, Rio de Janeiro, RJ, v. 22, n. 2, p. 383-392, 2017.

MENNUCCI, Tatiane Almeida et al. Avaliação da contaminação por matérias estranhas em carne de sol comercializada em "casas do norte". Revista do Instituto Adolfo Lutz, v. 69, n. 1, p. 47-54, 2010.

MOERMAN, Frank. Personal Hygiene and Good Maintenance Practices for the Servicing of Food Processing Equipment. In: Kennedy S. Food Protection and Security, Cambridge: Woodhead Publishing, p. 267-327, 2017.

NEVES, D. P. Parasitologia humana. 13. ed. São Paulo: Atheneu, 2016.

NOLL, Priscilla Rayane e Silva et al. Ultra-processed food consumption by Brazilian adolescents in cafeterias and school meals. Scientific Reports, v. 9, n. 1, p. 7.162, 2019.

NUNES, Daniele Monteiro et al. Surto de doença transmitida por alimento em evento de massa de populações indígenas em Cuiabá, Mato Grosso, Brasil, no ano de 2013. Epidemiologia e Serviços de Saúde, v. 25, n. 1, p. 1-10, 2016. ROCHA, Cleber Bastos et al. Efetividade da educação sanitária na redução dos riscos no comércio de produtos cárneos. Pubvet, v. 12, n. 6, p. 1-5, 2018.

SANTOS, Adenizia Souza et al. Frequência e preferência do consumo de carnes bovina, suína e aves por praticantes de exercícios físicos nas academias da cidade de Redenção-Pará. Revista Brasileira de Nutrição Esportiva, v. 11, n. 61, p. 87-92, 2017.

SANTOS, Danieli Muchalak et al. Diagnóstico situacional da adesão às boas práticas higiênicas em supermercados de um município da região metropolitana de Curitiba-PR, Brasil. Archives of Veterinary Science, v. 23, n. 3, p. 23-34, 2018. 
SILVA, Daiane Farias da et al. Análise coproparasitológica de manipuladores de alimentos em restaurantes especializados em gastronomia japonesa. Arquivos de Ciências da Saúde, v. 25, n. 1, p. 29-34, 2018.

SILVA, Neusely da; JUNQUEIRA Valéria Christina Amstalden; SILVEIRA, Neliane Ferraz de Arruda. Manual de métodos de análise microbiológica de alimentos. 5. ed. São Paulo: Blucher, 2017.

SILVA, Tamires Ramos da; FULCO, Tatiana de Oliveira; BARBOSA, Julio Viana. Investigação de artrópodes em alimentos na transmissão de doenças. Revista Episteme Transversalis, v. 6, n. 2, p. 85-105, 2017.

TRAVASSOS, Guilherme Fonseca; COELHO Alexandre Bragança. Padrão de substituição entre carnes no consumo domiciliar do Brasil. Revista de Economia e Sociologia Rural, v. 55, n. 2, p. 285-304, 2017.

VICENTINI, Mariana Scudeller. Alimentos industrializados: abordagem da indústria, consumidores e governo. Revista Segurança Alimentar e Nutricional, v. 22, n. 1, p. 671-682, 2015.

WU, Tao; LI, Liming. Evolution of Public Health Education in China. American Journal of Public Health, v. 107, n. 12, p. 1.893-1.895, 2017. 